\title{
SYNTHESIS AND BIOLOGICAL ACTIVITIES OF CYCLOPROPENONE ANTIBIOTIC PENITRICIN AND CONGENERS
}

\author{
Hidetoshi Tokuyama, Masahiko Isaka and Eirchi NaKamura* \\ Department of Chemistry, Tokyo Institute of Technology, \\ Meguro, Tokyo 152, Japan
}

Ryolchi ANDo and Yasuhiro Morinaka

Pharmaceuticals Laboratory, Research Center, Mitsubishi Kasei Corporation, 1000 Kamoshida-cho, Midori-ku, Yokohama 227, Japan

(Received for publication December 2, 1991)

\begin{abstract}
A number of derivatives of the cyclopropenone antibiotic penitricin have been synthesized by the reaction of metalated cyclopropenone acetals with electrophiles. Studies on the antimicrobial structure-activity relationships indicated that the penitricin skeleton, hydroxymethylcyclopropenone, is indispensable for antimicrobial activity. These compounds were also found to display cytotoxic activity.
\end{abstract}

Recently three naturally occurring compounds $\left(1^{1},{ }^{1} 2^{2)}\right.$ and $\left.3^{2)}\right)$ containing a highly strained cyclopropenone ring have been isolated. Among them, penitricin (1), isolated from the culture filtrate of Penicillium aculeatum by OKUDA et al., ${ }^{1)}$ is one of the rare classes of cyclopropenones known to have biological activity, ${ }^{3)}$ and it displays moderate activity against a broad range of Gram-positive and Gram-negative bacteria. The biosynthesis of penitricin has been investigated in some detail. ${ }^{4)}$ We recently developed the first general method for the synthesis of substituted cyclopropenones, ${ }^{5 \sim 7)}$ which is ideally suited for the synthesis of penitricin and its congeners. We report here the results of synthetic and biological studies on the penitricin class of antibiotics, focusing on the following issues: (1) the basic synthetic methodology, (2) the role of the cyclopropenone and the hydroxyl groups for the biological activity, and (3) the search for biological activity other than the antimicrobial one.

\section{Chemistry}

Only a limited range of substituted cyclopropenone derivatives have been studied for biological activity ${ }^{8)}$ due to the lack of efficient general methods for the synthesis of this interesting class of compounds. ${ }^{9,10)}$ Penitricin has been synthesized previously ${ }^{3)}$ in only $c a .1 \%$ overall yield, and no congeners have ever been prepared. With the aid of our general synthesis of cyclopropenones, ${ }^{5,6)}$ we have prepared penitricin and its congeners to gain the first insight into their structure-activity relationships. Representative penitricin congeners synthesized are listed in Table 1.

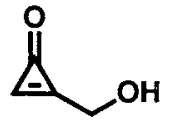

Penitricin (1)

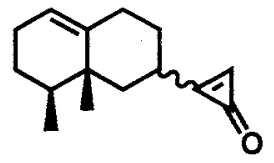

2

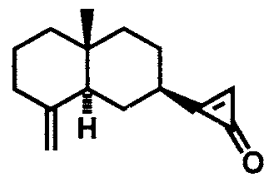

3 
Table 1. Synthesis of penitricin and its congeners.

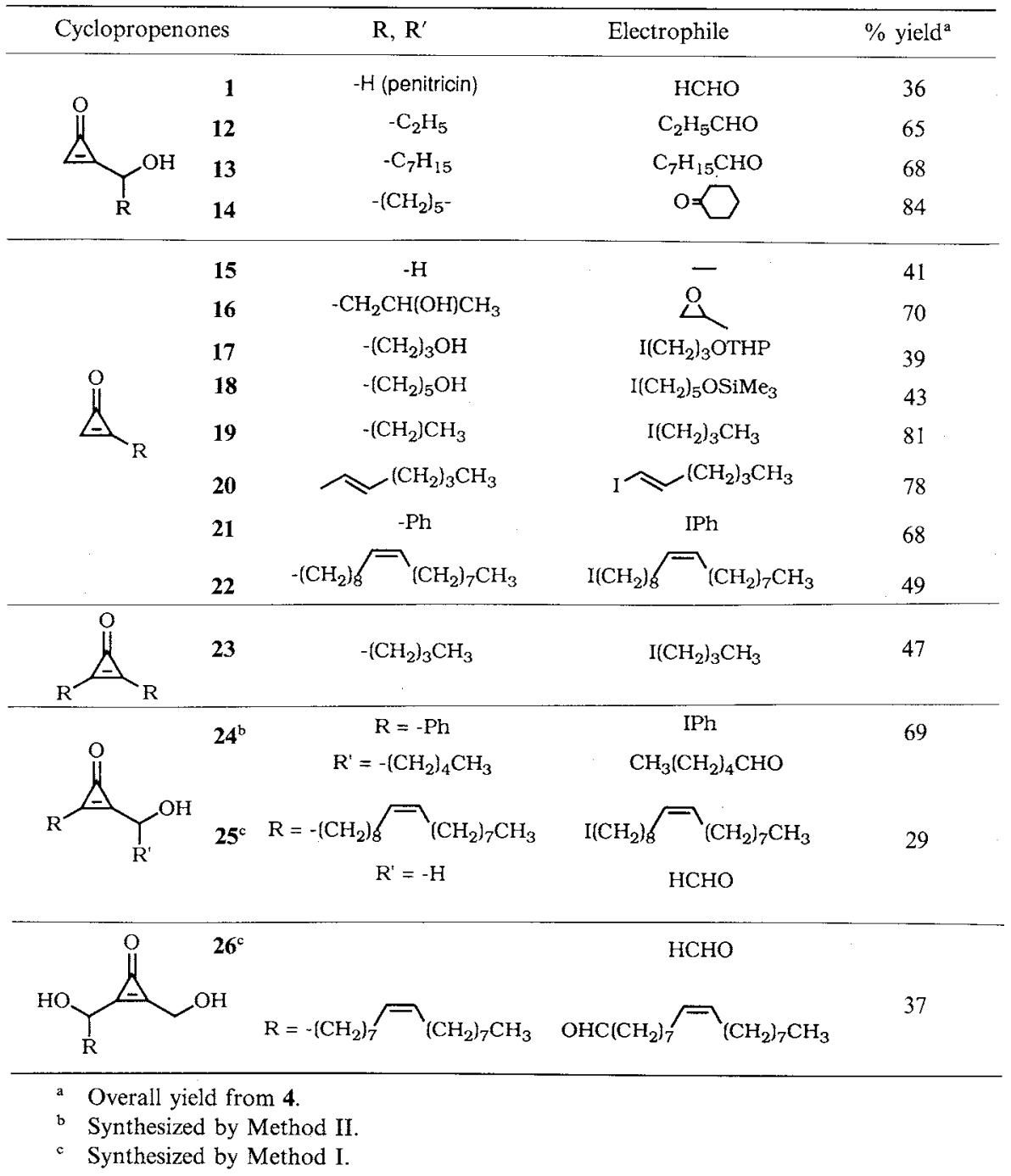

The strategy of our synthesis is summarized in Scheme 1. The synthesis basically relies on metalation of cyclopropenone acetal $\mathbf{4}$ or $\mathbf{8},{ }^{7 /}$ and subsequent reaction with electrophiles. Hydrolysis of the alkylated acetals gave rise to a variety of cyclopropenones. The average overall yield of the substituted cyclopropenone 11 is about $30 \sim 80 \%$.

The cyclopropenone acetal 4, available in two steps from 1,3-dichloroacetone in $82 \%$ yield, ${ }^{7}$ was converted to the corresponding lithium salt $5 \mathrm{a}$ by treatment with $n$-BuLi in THF at $-78^{\circ} \mathrm{C}$ in the presence of one or two equivalents of hexamethylphosphoric triamide or tetramethylethylenediamine. The reaction of 5a with electrophiles such as alkyl halides, carbonyl compounds and epoxides afforded the monosubstituted acetals. Alternatively, treatment of the lithium salt $\mathbf{5 a}$ with $\mathrm{ZnCl}_{2}$ followed by the palladium-catalyzed cross-coupling reaction ${ }^{11)}$ of the acetal zinc salt $\mathbf{5 b}$ with vinyl triflates, vinyl iodides and aryl iodides gave vinyl or aryl acetals.

Disubstituted acetals were synthesized via two different routes. In the first approach (Method I, 
<smiles>CC1(C)COC2(C=C2)CO1</smiles>

4

Scheme 1. Synthesis of penitricin and congeners.

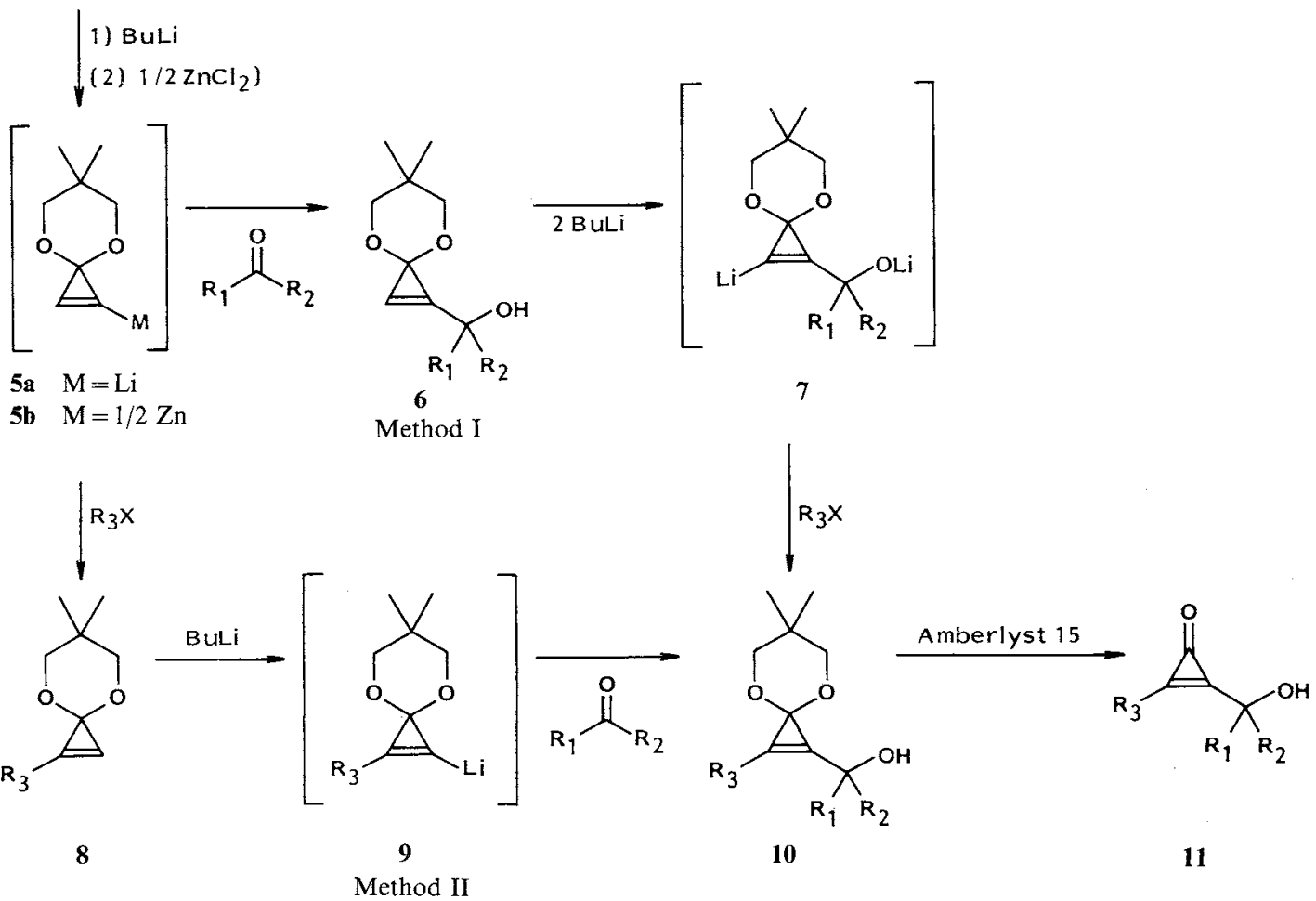

"dianion method"), the 1-hydroxyalkyl group was introduced first by the reaction of the lithium salt 5a with a carbonyl compound, and the adduct 6 was deprotonated with two equivalents of BuLi. Alkylation of the dianion 7 selectively proceeded at the vinyl position to give 10. In the second approach (Method II), an alkyl or aryl group was introduced first, and the hydroxyalkyl side chain group was introduced next. The overall efficiency of the two methods was roughly the same.

Hydrolysis of the acetal moiety in acetone or in aqueous THF proceeded readily with an acidic ion exchange catalyst, Amberlyst 15, to afford the corresponding cyclopropenones in nearly quantitative yield. Penitricin (1) was prepared as a white solid in $40 \sim 50 \%$ overall yield. This compound is soluble in water, wherein it decomposes slowly. Introduction of an alkyl side chain did not significantly improve the life time of the compounds in aqueous medium. Thus, half-life times of penitricin (1) and its congener 13 in $10 \%$ aqueous DMSO are less than half a day.

\section{Antibacterial Activity}

Some representative data are summarized in Table 2. Monosubstituted $\alpha$-hydroxycyclopropenones, $12 \sim 14$, showed an antibacterial activity comparable to that of penitricin. However, cyclopropenones lacking the $\alpha$-hydroxyl group $(15,19 \sim 21$ and 23 ) or those having its hydroxy group at the $\beta$-, $\gamma$ - or 
Table 2. Antimicrobial activity of cyclopropenones.

\begin{tabular}{|c|c|c|c|c|c|c|c|c|c|c|}
\hline \multirow{3}{*}{ Test organism } & \multicolumn{10}{|c|}{$\mathrm{MIC}(\mu \mathrm{g} / \mathrm{ml})$} \\
\hline & \multicolumn{10}{|c|}{ Cyclopropenone } \\
\hline & 1 & 12 & 13 & 14 & 15 & 16 & 17 & 18 & 22 & 26 \\
\hline Enterobacter cloacae IFO 963 & 100 & 100 & 50 & 100 & $>300$ & 300 & $>300$ & 300 & $>300$ & $>100$ \\
\hline Escherichia coli NIHJ JC-2 & 100 & 100 & 50 & 100 & $>300$ & 300 & $>300$ & 300 & $>300$ & $>100$ \\
\hline Klebsiella pneumoniae PCI 602 & 33 & 33 & 25 & 50 & $>300$ & 300 & $>300$ & 300 & $>300$ & $>100$ \\
\hline Pseudomonas aeruginosa IFO 3445 & 33 & 33 & $>100$ & $>100$ & 300 & 100 & $>300$ & $>300$ & $>300$ & $>100$ \\
\hline$P$. aeruginosa $\mathrm{PAOI}$ & 33 & 33 & $>100$ & 100 & $>300$ & 100 & $>300$ & 300 & 33 & $>100$ \\
\hline Proteus morganii IFO 3848 & 33 & 33 & 12.5 & 50 & 300 & 300 & $>300$ & 300 & 100 & $>100$ \\
\hline$P$. rettgeri IFO 3850 & 33 & 33 & 25 & 50 & $>300$ & 300 & $>300$ & 300 & $>300$ & $>100$ \\
\hline P. vulgaris $\mathrm{OX}-19$ & 33 & 33 & 25 & 50 & 300 & 100 & $>300$ & 300 & 100 & $>100$ \\
\hline Salmonella enteritidis G14 & 33 & 33 & 50 & 50 & 300 & 300 & $>300$ & 300 & $>300$ & $>100$ \\
\hline Bacillus subtilis AТCC 6633 & 100 & 100 & 50 & 100 & 100 & 300 & $>300$ & $>300$ & 100 & 100 \\
\hline Micrococcus luteus AТCC 9341 & 33 & 33 & 50 & 100 & 300 & n.d. & n.d. & n.d. & n.d. & 11 \\
\hline $\begin{array}{l}\text { Staphylococcus aureus } \\
\text { FDA 209P JC-1 }\end{array}$ & $>100$ & 100 & 100 & $>100$ & 100 & 300 & $>300$ & $>300$ & 33 & 11 \\
\hline S. aureus MS353 & $>100$ & 100 & 100 & $>100$ & 100 & 300 & $>300$ & $>300$ & 33 & 3.7 \\
\hline
\end{tabular}

$\varepsilon$-position of the side chain $(16 \sim 18)$ showed very weak or no activity at all. Notably, the disubstituted cyclopropenones such as $\mathbf{2 4}$, bearing an $\alpha$-hydroxy group on the side chain, are also inactive. Interestingly, highly lipophilic compounds bearing a long aliphatic side chains 22 and 26 exhibit sizable activity against Gram-positive bacteria. For all series of compounds, the corresponding cyclopropenone acetals did not show any antibacterial activity. In conclusion, the monosubstituted $\alpha$-hydroxymethylcyclopropenone structure in penitricin has been found to be necessary for the antibiotic activity.

\section{Cytotoxicity}

Most of the above cyclopropenones were also
Table 3. Cytotoxicity (HeLa S3) of cyclopropenones and their acetals.

\begin{tabular}{cc}
\hline Cyclopropenones & $\mathrm{ED}_{50}(\mu \mathrm{g} / \mathrm{ml})^{\mathrm{a}}$ \\
\hline $\mathbf{2 4}$ & 2.00 (n.d.) \\
$\mathbf{1 3}$ & 2.3 (n.d.) \\
$\mathbf{1 6}$ & $2.32(14.5)$ \\
$\mathbf{1 8}$ & $2.44(7.18)$ \\
$\mathbf{1 4}$ & 2.7 (n.d.) \\
$\mathbf{2 5}$ & $3.4(12.1)$ \\
$\mathbf{1 5}$ & $5.75(20.4)$ \\
$\mathbf{1 7}$ & $5.88(8.73)^{\mathrm{b}}$ \\
$\mathbf{2 6}$ & $21.3(20.2)$ \\
$\mathbf{2 2}$ & $62.8(24.8)$ \\
$\mathbf{2 1}$ & $81.6(40.2)$ \\
$\mathbf{2 3}$ & 223.2 (n.d.) \\
\hline
\end{tabular}

a Data for the corresponding acetals in brackets.

b Hydroxyl group was protected as THP ether.

examined for their cytotoxicity against the HeLa S3 cell line. The representative effective dose values $\left(\mathrm{ED}_{50}\right)$ are listed in Table 3. The structure-activity relationship is quite different from that of the antibacterial activity. The $\alpha$-hydroxy group which proved so important for the antibacterial activity was found to be irrelevant for the cytotoxicity. Some cyclopropenone acetals also exhibited cytotoxicity. The activity largely depends on the number of substituents on the cyclopropenone ring. The parent cyclopropenone and monosubstituted derivatives showed moderate cytotoxicity and disubstituted compounds showed much weaker activity.

In summary, we have synthesized a number of cyclopropenones and examined their biological activity to find that the $\alpha$-hydroxymethylcyclopropenone structure is necessary for the antibacterial activity. The structure-activity profile of the cytotoxicity is very different from the antibacterial spectrum, suggesting that the mechanism of action is different. 


\section{Experimental}

Antibacterial Activity

MICs were determined by the 2- or 3-fold agar dilution method using Sensitive Test agar (Nissui, Japan) after incubation at $37^{\circ} \mathrm{C}$ for 18 hours with incolumn size of $10^{6} \mathrm{cfu} / \mathrm{ml}$.

\section{Cytotoxicity}

HeLa S3 cells were grown at $37^{\circ} \mathrm{C}$ as suspensions in DMEM medium containing $10 \%$ fetal calf serum. Exponentially growing HeLa S3 cells were seeded in tubes at $10^{5} \mathrm{cells} / \mathrm{ml}$ and the compounds were added at different concentrations at day 0 . After cells were allowed to grow for 3 days at $37^{\circ} \mathrm{C}$, final cell numbers were measured by the MTA method. ${ }^{12)}$ The $\mathrm{ED}_{50}$ were estimated by regression analysis concentration-response data.

\section{Chemistry: General}

${ }^{1} \mathrm{H}$ NMR $(200,270$ and $500 \mathrm{MHz})$ and ${ }^{13} \mathrm{C}$ NMR $(50,67.5$ and $125 \mathrm{MHz})$ spectra were measured for a $\mathrm{CDCl}_{3}$ solution of samples of Jeol FX-200, GSX-270 and GSX-500 instruments. ${ }^{1} \mathrm{H}$ NMR spectra are reported in parts per million from internal tetramethylsilane, and ${ }^{13} \mathrm{C} \mathrm{NMR} \mathrm{spectra} \mathrm{from} \mathrm{CDCl}_{3}$ $(77.0 \mathrm{ppm})$. IR spectra were recorded on a Hitachi 260-10 instrument or a Jasco IR-800; absorptions are reported in $\mathrm{cm}^{-1}$. All reactions using air and moisture sensitive compounds were carried out in a dry vessel under nitrogen. Ethereal solvents were distilled from sodium benzophenone ketyl immediately before use. Hexamethylphosphoric triamide (HMPA) was distilled from calcium hydride under nitrogen and stored over molecular sieves. Tetramethylethylenediamine (TMEDA) was distilled from calcium hydride and stored under nitrogen. Routine chromatography was performed on silica gel using a mixture of ethyl acetate and hexane as eluant.

\section{2-Hydroxymethyl-2-cyclopropen-1-one (1)}

To a solution of the cyclopropenone acetal $4(2.5 \mathrm{ml}, 18 \mathrm{mmol})$ and TMEDA $(4.1 \mathrm{ml}, 27 \mathrm{mmol})$ in THF $(45 \mathrm{ml})$ at $-70^{\circ} \mathrm{C}$ was added $\mathrm{BuLi}(11.9 \mathrm{ml}$ of a $1.59 \mathrm{M}$ solution in hexane, $18.9 \mathrm{mmol})$ over 5 minutes, and the mixture was stirred for 20 minutes. The reaction mixture was warmed to $-40^{\circ} \mathrm{C}$, and formaldehyde gas (thermolysis of $3.0 \mathrm{~g}$ of paraformaldehyde at $160^{\circ} \mathrm{C}$ ), was bubbled into the solution over 30 minutes (carrier gas: nitrogen). The reaction was terminated by addition of a $\mathrm{pH} 7.4$ phosphate buffer - THF solution $(1-5,10 \mathrm{ml})$. The mixture was filtered through a short column of Celite-silica gel (elution with $\mathrm{Et}_{2} \mathrm{O}$ ). $\mathrm{The}$ filtrate was concentrated to obtain an oily crude product $(4.1 \mathrm{~g})$. Column chromatography on silica gel ( 20 to $70 \%$ ethyl acetate in hexane) afforded the penitricin acetal $\left(6: R_{1}=R_{2}=H, 1.56 \mathrm{~g}, 51 \%\right.$ ). Further purification was achieved by recrystallization from $\mathrm{Et}_{2} \mathrm{O}$ - hexane.

The penitricin acetal $(124 \mathrm{mg}, 0.73 \mathrm{mmol})$ was dissolved in THF $(0.7 \mathrm{ml})$ and water $(66 \mu \mathrm{l})$. Amberlyst $15(21 \mathrm{mg})$ was added and the suspension was stirred for 20 minutes. The resin was removed to obtain a yellow oil ( $94 \%$ yield by ${ }^{1} \mathrm{H}$ NMR analysis). Column chromatography on silica gel ( $\mathrm{Et}_{2} \mathrm{O}$, then with ethyl acetate) gave penitricin (1) as a yellow oil $(43.5 \mathrm{mg}, 71 \%$ ). Further purification by silica gel column chromatography (ethyl acetate) afforded a pure sample as a white solid, which could be stored in a $-20^{\circ} \mathrm{C}$ freezer for more than three month without loss of purity. The spectral properties fully coincided with the reported values: ${ }^{3)} \mathrm{IR}$ (neat) $\mathrm{cm}^{-1} 3350,1940,1835,1585,1065,640 ;{ }^{1} \mathrm{H} \mathrm{NMR}\left(200 \mathrm{MHz}, \mathrm{CDCl}_{3}\right) \delta 3.41(1 \mathrm{H}$, br s), $4.79(2 \mathrm{H}, \mathrm{br} \mathrm{s}), 8.56(1 \mathrm{H}, \mathrm{t}, J=1.3 \mathrm{~Hz}) ;{ }^{13} \mathrm{C} \mathrm{NMR}\left(67.5 \mathrm{MHz}, \mathrm{CDCl}_{3}\right) \delta 58.8,146.7,156.3,169.5$.

Anal Calcd for $\mathrm{C}_{4} \mathrm{H}_{4} \mathrm{O}_{2}$ : C $54.14, \mathrm{H} 4.80$.

Found: $\quad$ C $53.92, \mathrm{H} 4.94$

General Procedure for the Preparation of 2-Substituted Cyclopropenones via 5a

2-(1-Hydroxyoctyl)-2-cyclopropen-1-one (13)

To a solution of cyclopropenone acetal $4(0.93 \mathrm{ml}, 6.6 \mathrm{mmol})$ and TMEDA $(2.72 \mathrm{ml}, 18 \mathrm{mmol})$ in THF $(10 \mathrm{ml})$ at $-70^{\circ} \mathrm{C}$ was added $3.77 \mathrm{ml}$ of $\mathrm{BuLi}(6.6 \mathrm{mmol}$ in hexane) over 5 minutes. After stirring for 0.5 hour, octanal $(0.94 \mathrm{ml}, 6 \mathrm{mmol})$ was added dropwise, and stirred for 1 hour at that temperature. The reaction was terminated by addition of a $\mathrm{pH} 7.4$ phosphate buffer $(1 / 15 \mathrm{M})$ in THF $(1: 5,3.5 \mathrm{ml})$. Purification of the crude product $(2.2 \mathrm{~g})$ on silica gel gave the acetal of $13(1.34 \mathrm{~g}, 85 \%)$. 
To a solution of the acetal $(1.07 \mathrm{~g}, 4 \mathrm{mmol})$ in THF $(6 \mathrm{ml})$ was added Amberlyst $15(100 \mathrm{mg})$. The mixture was stirred for 2 hours at room temperature, filtered and concentrated to afford a crude oily product. Purification on silica gel gave $13(0.58 \mathrm{~g}, 81 \%)$ : IR (neat) $\mathrm{cm}^{-1} 3400,2930,2860,1830,1590,1465$, $1080 ;{ }^{1} \mathrm{H} \mathrm{NMR}\left(270 \mathrm{MHz}, \mathrm{CDCl}_{3}\right) \delta 0.88(3 \mathrm{H}, \mathrm{d}, J=6.35 \mathrm{~Hz}), 1.19 \sim 1.42(8 \mathrm{H}, \mathrm{m}), 1.42 \sim 1.58(2 \mathrm{H}, \mathrm{m})$, $1.73 \sim 1.90(2 \mathrm{H}, \mathrm{m}), 2.63(1 \mathrm{H}, \mathrm{d}, J=5.37 \mathrm{~Hz}), 4.82(1 \mathrm{H}, \mathrm{dt}, J=5.37$ and $5.86 \mathrm{~Hz}), 8.51(1 \mathrm{H}, \mathrm{d}, J=1.98 \mathrm{~Hz})$.

Anal Calcd for $\mathrm{C}_{11} \mathrm{H}_{18} \mathrm{O}_{2}: \quad \mathrm{C} 72.49, \mathrm{H} 9.95$. Found: $\quad$ C $72.30, \mathrm{H} 9.98$.

General Procedure for the Preparation of 2-Substituted Cyclopropenones via $\mathbf{5 b}$

2-(trans-1-Hexenyl)-2-cyclopropen-1-one (20)

To a solution of the cyclopropenone acetal $4(2.95 \mathrm{ml}, 21 \mathrm{mmol})$ and HMPA $(12.2 \mathrm{ml}, 70 \mathrm{mmol})$ in THF $(30 \mathrm{ml})$ at $-70^{\circ} \mathrm{C}$ was added $\mathrm{BuLi}(12.9 \mathrm{ml}$ of a $1.63 \mathrm{M}$ solution in hexane, $21 \mathrm{mmol})$ over 6 minutes and the mixture was stirred for 30 minutes. Zinc chloride $(10.5 \mathrm{ml}$ of a $1 \mathrm{M}$ solution in THF, $10.5 \mathrm{mmol})$ was added, and the dry ice/hexane bath was removed. trans-1-Iodo-1-hexene $(2.0 \mathrm{ml}, 14 \mathrm{mmol})$ and $\mathrm{Pd}\left(\mathrm{PPh}_{3}\right)_{4}(0.75 \mathrm{~g}, 0.70 \mathrm{mmol})$ were added, and the mixture was stirred at room temperature for 2 hours. Triethylamine $(0.7 \mathrm{ml})$ was added, and the solution was diluted with hexane and passed through silica gel $\left(27 \mathrm{~g}, 20 \% \mathrm{Et}_{2} \mathrm{O}\right.$ in hexane). The filtrate was concentrated to afford an orange oil $(3.5 \mathrm{~g})$. Column chromatography on silica gel (5\% ethyl acetate in hexane) afforded the acetal of $\mathbf{2 0}$ as a colorless oil $(2.92 \mathrm{~g}, 94 \%)$.

To a solution of the acetal compound $(49.2 \mathrm{mg}, 0.22 \mathrm{mmol})$ in acetone $(2 \mathrm{ml})$ was added Amberlyst $15(7.5 \mathrm{mg})$, and the mixture was stirred for 20 minutes. The mixture was filtered and concentrated to afford a crude oily product. Purification on silica gel afforded $20\left(25.1 \mathrm{mg}, 84 \%\right.$ ): IR (neat) $\mathrm{cm}^{-1} 3050$, $1830,1640,1570 ;{ }^{1} \mathrm{H}$ NMR $\left(200 \mathrm{MHz}, \mathrm{CDCl}_{3}\right) \delta 0.93(3 \mathrm{H}, \mathrm{t}, J=7.4 \mathrm{~Hz}), 1.25 \sim 1.60(4 \mathrm{H}, \mathrm{m}), 2.25 \sim 2.40$ $(2 \mathrm{H}, \mathrm{m}), 6.21(1 \mathrm{H}$, ddt, $J=15.6,1.3$ and $1.3 \mathrm{~Hz}), 6.96(1 \mathrm{H}, \mathrm{dt}, J=15.6$ and $6.9 \mathrm{~Hz}), 8.09(1 \mathrm{H}, \mathrm{d}, J=1.3 \mathrm{~Hz})$.

$\begin{array}{ll}\text { Anal Calcd for } \mathrm{C}_{9} \mathrm{H}_{12} \mathrm{O}: & \mathrm{C} 79.39, \mathrm{H} 8.88 . \\ \text { Found: } & \text { C 79.11, H } 8.63 .\end{array}$

General Procedure for the Preparation of 2,3-Disubstituted Cyclopropenones via Dianion 7

2-Hydroxymethyl-3-oleyl-2-cyclopropen-1-one (25)

To a solution of penitricin acetal $\left(6, \mathrm{R}_{1}=\overline{\mathrm{R}_{2}=\mathrm{H}}\right)(74.7 \mathrm{mg}, 0.439 \mathrm{mmol})$ and HMPA $(0.229 \mathrm{ml}$, $1.32 \mathrm{mmol})$ in THF $(1.5 \mathrm{ml})$ at $-70^{\circ} \mathrm{C}$ was added $0.57 \mathrm{ml}$ of $\mathrm{BuLi}(0.92 \mathrm{mmol}$ in hexane $)$ over 3 minutes, and the mixtures was stirred for 0.5 hour. Oleyl iodide $(170 \mu \mathrm{l}, 0.66 \mathrm{mmol})$ was added and stirred for 8 hours at that temperature. A solution of a $\mathrm{pH} 7.4$ phosphate buffer in THF $(0.24 \mathrm{ml})$ was added to the mixture, which was then diluted with hexane. The mixture was passed through silica gel $\left(\mathrm{Et}_{2} \mathrm{O}\right)$, and concentrated to obtain $0.32 \mathrm{~g}$ of an orange oil. Column chromatography on silica gel afforded the acetal of $25(114 \mathrm{mg}, 62 \%)$.

To a solution of the disubstituted acetal $(67.3 \mathrm{mg}, 0.16 \mathrm{mmol})$ in THF $(0.3 \mathrm{ml})$ was added Amberlyst 15 and water $(14 \mu \mathrm{l})$. The suspension was stirred for 15 minutes. Filtration and concentration afforded a crude oily product. Purification on silica gel gave the title compound $(48.9 \mathrm{mg}, 91 \%)$ : IR (neat) $\mathrm{cm}^{-1}$ $3350,2920,2850,1850,1625,1060 ;{ }^{1} \mathrm{H}$ NMR $\left(200 \mathrm{MHz}, \mathrm{CDCl}_{3}\right) \delta 0.89(3 \mathrm{H}, \mathrm{m}), 1.2 \sim 1.4(22 \mathrm{H}, \mathrm{m}), 1.71$ $(2 \mathrm{H}, \mathrm{m}), 2.02(4 \mathrm{H}, \mathrm{m}), 2.66 \sim 2.70(3 \mathrm{H}, \mathrm{m}), 4.76(2 \mathrm{H}, \mathrm{d}, J=5.7 \mathrm{~Hz}), 5.34 \sim 5.37(2 \mathrm{H}, \mathrm{m})$.

Anal Calcd for $\mathrm{C}_{22} \mathrm{H}_{38} \mathrm{O}_{2}$ : C 78.99, $\mathrm{H} 11.45$.

Found:

C $79.00, \mathrm{H} 11.48$.

\section{Acknowledgment}

The authors thank Mr. Yoshimitsu MiYaCH for the preparation of penitricin and Mr. JUNICHI OHYA for the biological assay.

\section{References}

1) Okuda, T.; K. Yokose, T. Furumai \& H. B. Maruyama: Penitricin, a new class of antibiotics produced by Penicillium aculeatum. II. Isolation and characterization. J. Antibiotics 37: 718 722, 1984

2) Bohlmann, F.; J. Jakupovic, L. Mueller \& A. Schuster: Naturally occurring cyclopropenone derivatives. Angew. 
Chem. Int. Ed. Engl. 20: 292 293, 1981

3) Okuda, T.; N. Shimma \& T. Furumal: Penitricin, a new class of antibiotic produced by Penicillium aculeatum. III. Structural confirmation by chemical synthesis and biological activity. J. Antibiotics 37: 723 727, 1984

4) Okuda, T. \& T. Furumai: Penitricin, a new class of antibiotic produced by Penicillium aculeatum. IV. Biosynthesis. J. Antibiotics 38: $631 \sim 635,1985$

5) Isaka, M.; S. Matsuzawa, S. Ymago, S. Ejiri, Y. Miyachi \& E. Nakamura: Application of metalated cyclopropenone ketals in a general synthesis of cyclopropenones. An efficient synthesis of the antibiotic penitricin. J. Org. Chem. 54: 4727 4729, 1989

6) ISAKA, M.; S. EJIRI \& E. NAKAMURA: General synthesis of cyclopropenones and their acetals. Tetrahedron 48: $2045 \sim 2057,1992$.

7) IsAKA, M.; R. ANDO, Y. MoRINAKa \& E. NAKAMURA: One-pot synthesis of substituted cyclopropenone ketals via alkylation of 3,3-dialkoxy-2-sodiocyclopropenes. Tetrahedron Lett. 32: 1339 1342, 1991

8) Stute, von J; B. M. Hausen \& K. H. Shultz: Diphenylcyclopropenoneein stark wirksames Kontaktallergen. Dermatosen in Beruf und Umwelt 29: 12 15, 1981

9) . Pots, K. T. \& J. S. Baum: The Chemistry of cyclopropenones. Chem. Rev. 57: 189 213, 1974

10) Eicher, T. \& J. L. WerER: Structure and reactivity of cyclopropenones and triafulvenes. Top. Curr. Chem. 57 : $3 \sim 109,1975$

11) Negishi, E.; L. F. Valente \& M. Kobayashi: Palladium-catalyzed cross-coupling reaction of homoallylic or homopropargylic organozincs with alkenyl halides as a new selective route to 1,5-dienes and 1,5-enynes. J. Am. Chem. Soc. 102: 3298 3299, 1980

12) Alley, M. C.; D. A. Scudiero, A. Monks, M. I. Hursey, M. J. Czerwinski, D. L. Fine, B. J. Abotr, J. G. Mayo, R. H. ShoEmaker \& M. R. Boyd: Feasibility of drug screening with panels of human tumor cell lines using a microculture tetrazolium assay. Cancer Res. 48: 589 601, 1988 